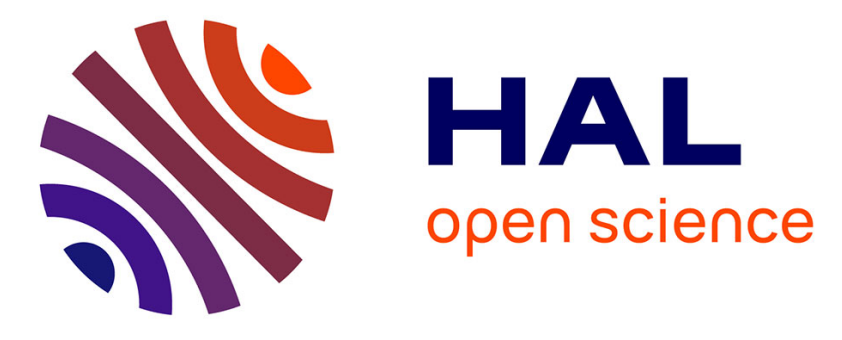

\title{
Electron tunnelling of GaAs-Pb junctions under high pressure
}

\author{
J.P. Sorbier, P. Nédellec
}

\section{To cite this version:}

J.P. Sorbier, P. Nédellec. Electron tunnelling of GaAs-Pb junctions under high pressure. Journal de Physique Lettres, 1978, 39 (22), pp.443-446. 10.1051/jphyslet:019780039022044300 . jpa-00231539

\section{HAL Id: jpa-00231539 https://hal.science/jpa-00231539}

Submitted on 1 Jan 1978

HAL is a multi-disciplinary open access archive for the deposit and dissemination of scientific research documents, whether they are published or not. The documents may come from teaching and research institutions in France or abroad, or from public or private research centers.
L'archive ouverte pluridisciplinaire HAL, est destinée au dépôt et à la diffusion de documents scientifiques de niveau recherche, publiés ou non, émanant des établissements d'enseignement et de recherche français ou étrangers, des laboratoires publics ou privés. 


\title{
ELECTRON TUNNELLING OF GaAs-Pb JUNCTIONS UNDER HIGH PRESSURE
}

\author{
J. P. SORBIER and P. NÉDELLEC (*)
}

Groupe de Physique, Université de Provence, rue Henri-Poincaré, 13397 Marseille Cedex 4, France

$\left(^{*}\right)$ Laboratoire de Physique des Solides ${ }^{+}$. Université Paris-Sud, 91405 Orsay, France

(Reçu le 13 juillet 1978, révisé le 29 septembre 1978, accepté le 2 octobre 1978)

\begin{abstract}
Résumé. - Par effet tunnel sur des barrières de Schottky GaAs-Pb, on a étudié la déformation de la bande de conduction et la variation de l'énergie du phonon LO du GaAs, ainsi que la température critique, la bande d'énergie interdite et les énergies caractéristiques de phonons d'un film supraconducteur de plomb en fonction de la pression jusqu'à 30 kbar. On a établi une corrélation entre la variation des différents paramètres supraconducteurs.
\end{abstract}

\begin{abstract}
The conduction band distortion and LO phonon energy of GaAs, the transition temperature, the energy gap and the phonon energies in superconducting lead film, have been measured at pressures up to $30 \mathrm{kbar}$ by electron tunnelling through Schottky barriers.
\end{abstract}

The change of the superconducting tunnelling density of states of strong coupling superconductors can be studied successfully by using Schottky barriers as the first tunnelling electrode up to very high pressures [1]. (In fact, the conventional metal-oxidemetal junctions have been used, up to now, for pressures not greater than 14 kbar [2].) However, due to the strong variation of the background tunnelling resistance, the density of states of both electrodes must be considered simultaneously.

In this letter, we report on a study of $\mathrm{GaAs}-\mathrm{Pb}$ junctions at hydrostatic pressures up to $30 \mathrm{kbar}$. We have investigated, by the electron tunnelling method, the effect of pressure on the superconducting critical temperature $T_{\mathrm{c}}$, the energy gap $\Delta(0)$ and the $\mathrm{TA}$ and $\mathrm{LA}$ energies phonons of $\mathrm{Pb}$.

The junctions were made on a $n$ type GaAs single crystal, oriented along the [111] axis, doped with $\mathrm{Te}$ $\left(N_{\mathrm{d}}=5.6 \times 10^{18}\right.$ impurities $\left.\mathrm{cm}^{-3}\right)$. The surface of the GaAs is chemically polished according to the procedure described by Guétin and Schreder [3]. After introduction into a high vacuum system the surface is bombarded by $50 \mathrm{eV} \mathrm{Ar}$ ions (the ions current is about $10^{11}$ ions $\mathrm{cm}^{-2}$ ) and is not annealed afterwards. Next, the $\mathrm{Pb}$ film is evaporated, under a pressure below $10^{-9}$ torr. Its thickness is $1 \mu \mathrm{m}$ and a typical area of a $\mathrm{Pb}$ dot is $1 \mathrm{~mm}^{2}$.

The sample is immersed in the teflon pressure cell filled with the pressure transmitting fluid (isopentane

$\left(^{+}\right)$Laboratoire associé au C.N.R.S. L.A. $\mathrm{n}^{\circ} 2$. and isoamelic alcohol mixture). The hydrostatic pressure system is a double stage steel bomb delivering a pressure between 0 to $35 \mathrm{kbar}$ in a range of temperature between $2 \mathrm{~K}$ and room temperature [4]. The high pressure stage uses a teflon cell which acts as an automatic pressure seal. The pressure is measured using the resistance variation of a manganin gauge placed inside the teflon cell : precision of the experimental pressure data is $\pm 0.5 \mathrm{kbar}$.

Figure 1 gives the variation of the tunnelling resistance $\mathrm{d} V / \mathrm{d} I$ at zero bias versus the applied pressure $P$ at $300 \mathrm{~K}$, for several junctions. The increase of the resistance with $P$ can be described by two linear variations which show a nearly exponential variation in each domain. The behaviour between 0 to $20 \mathrm{kbar}$ can be explained in terms of the barrier height variation; the slope $\mathrm{d}(\mathrm{d} V / \mathrm{d} I) / \mathrm{d} P$ is identical to values reported for GaAs junctions prepared on a cleaved surface [5]. At $20 \mathrm{kbar}$, a slope difference appears. The Aspnes model for the GaAs conduction band shows that the inversion of the low-energy valleys $\Gamma_{L}$ and $\Gamma_{X}$ of the conduction band appears respectively above $25 \mathrm{kbar}$ and $40 \mathrm{kbar}$ [6]. The same result was found by Pitt and Lees [7]. So the second domain in figure 1 is probably due to the limitation of $\mu_{\mathrm{F}}(000)$, the Fermi degeneracy in the central direction, by the upper valley $L$ which gives a transfer, in GaAs, of electrons from the $\Gamma$ to the $L$ minima. Attempts made to obtain the second inversion gap at higher pressures have not been convincing.

The energy of the LO phonon of GaAs varies 


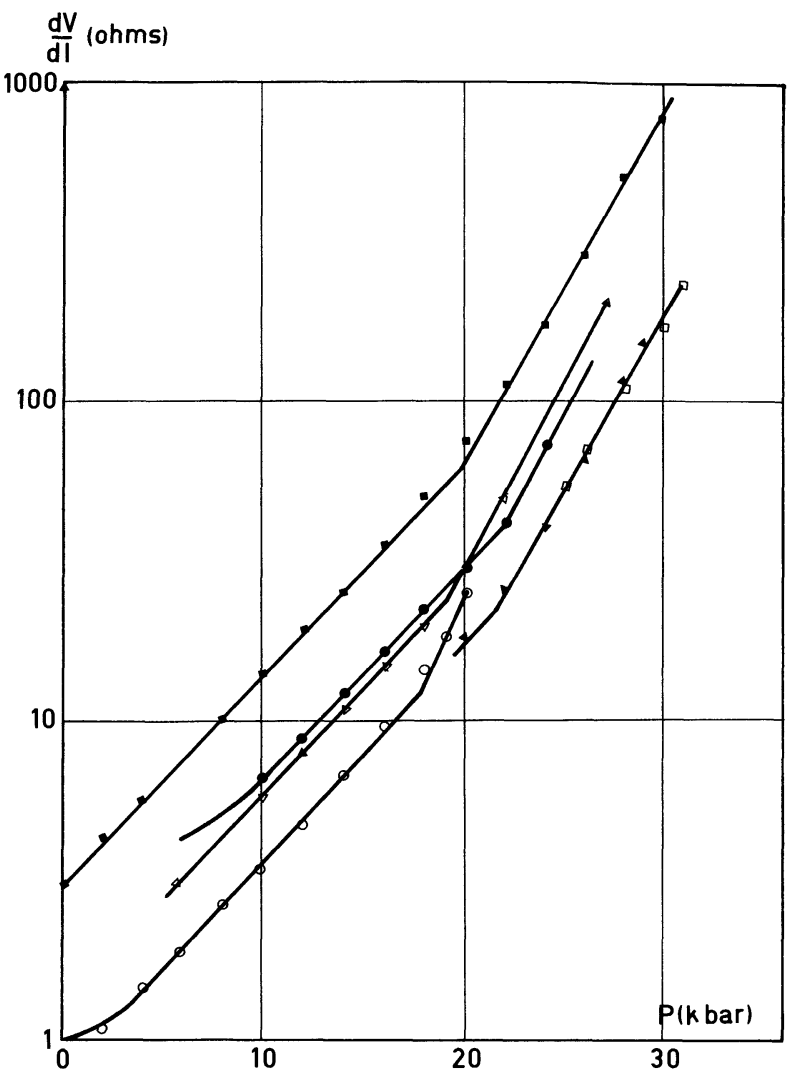

Fig. 1. - Pressure dependence of $(\mathrm{d} V) /(\mathrm{d} I)$ at null bias at $300 \mathrm{~K}$, for several functions.

linearly with pressure as shown in figure 2 . The slope $\mathrm{d} \omega_{\mathrm{LO}} / \mathrm{d} P$ is $(7.0 \pm 0.2) 10^{-5} \mathrm{meV} / \mathrm{kbar}$ and the experimental data points are in good agreement with previously reported results [5].

The variation of $T_{\mathrm{c}}$ and $\Delta(0)$ with pressure are shown in figure 3. $T_{\mathrm{c}}$ was determined by the first departure of the zero bias tunnelling conductance from its normal state value. $\Delta(0)$ was calculated from the tunnelling conductance using standard techniques [8]. The pressure dependence of $\Delta(0)$ and $T_{c}$

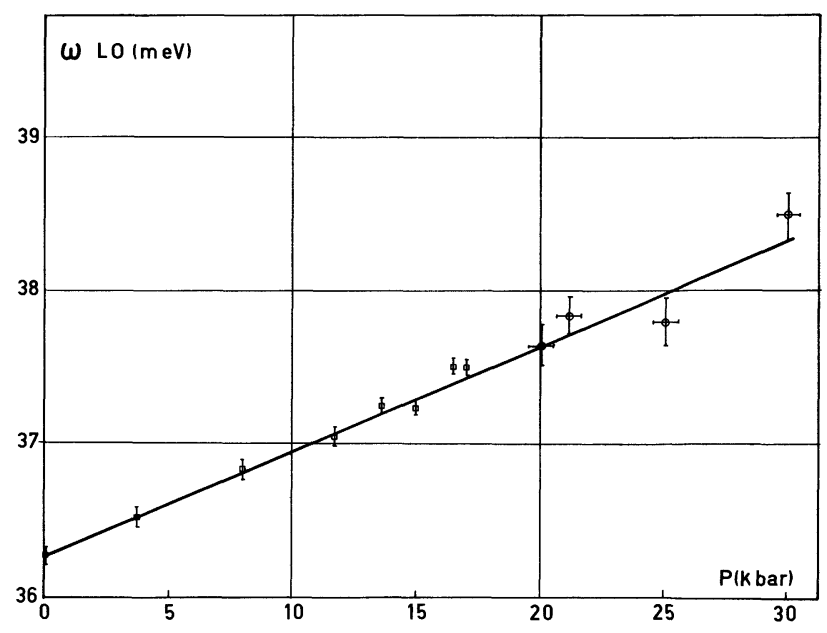

FIG. 2. - Pressure dependence of the zone centre optical phonon energy of GaAs. ( $\square$ ) are for the reference [5].

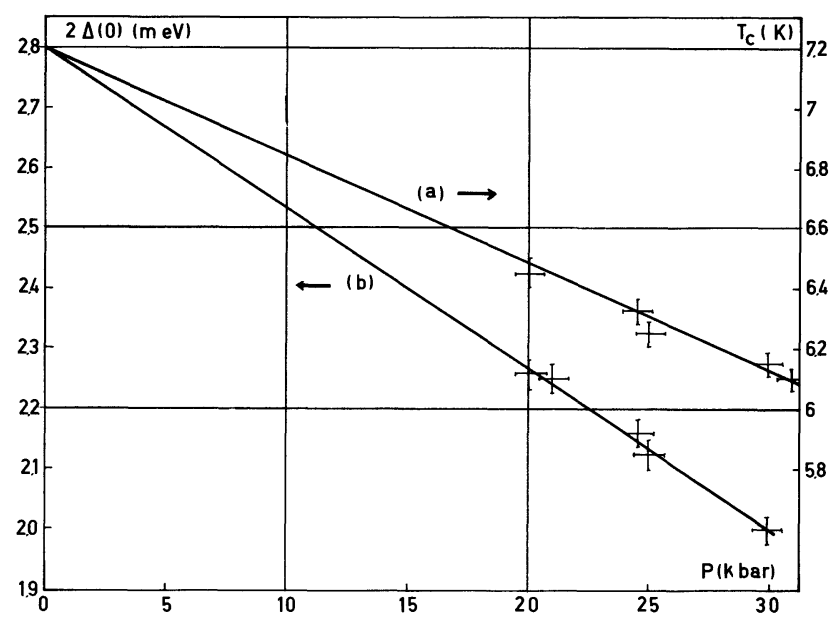

Fig. 3. - Critical temperature (curve a) and energy gap (curve b) versus pressure for superconducting lead.

can be described by straight lines whose slopes are given in table $\mathrm{I}$. The ratio $2 \Delta(0) / k_{\mathrm{B}} T_{\mathrm{c}}$ which decreases

\section{TABLE I}

Pressure dependence of some superconductive parameters measured by tunnelling effect on $\mathrm{Pb}$

\begin{tabular}{|c|c|c|c|c|c|c|}
\hline \multirow[b]{2}{*}{$X$} & \multicolumn{2}{|c|}{$\mathrm{d} X / \mathrm{d} P \times 10^{6}$} & \multicolumn{2}{|c|}{$\mathrm{d} \log X / \mathrm{d} P \times 10^{6} \mathrm{bar}^{-1}$} & \multicolumn{2}{|c|}{$\mathrm{d} \log X / \mathrm{d} \ln V$} \\
\hline & our results & previous results & our results & previous results & our results & previous results \\
\hline - & - & - & - & - & - & - \\
\hline $\begin{array}{c}T_{\mathrm{c}} \\
(\mathrm{K})\end{array}$ & $-35.5 \pm 0.2 \mathrm{~K} \mathrm{bar}^{-1}$ & $\begin{array}{c}-36.1 \mathrm{~K} \mathrm{bar}^{-1} \\
{[11]}\end{array}$ & $-5.55 \pm 0.1$ & $\begin{array}{c}-5.27 \pm 0.1 \\
{[10]}\end{array}$ & & \\
\hline $\begin{array}{l}\Delta(0) \\
(\mathrm{meV})\end{array}$ & $-13.2 \pm 0.1 \mathrm{meV} \mathrm{bar}^{-1}$ & $\begin{array}{c}-12.25 \pm 0.15 \mathrm{meV} \mathrm{bar}^{-1} \\
{[2]} \\
-12.2 \pm 0.1 \mathrm{meV} \mathrm{bar}^{-1} \\
{[5]}\end{array}$ & -11.53 & $-8.6 \pm 0.5$ & & \\
\hline $\begin{array}{c}\omega_{\mathrm{TA}} \\
(\mathrm{meV})\end{array}$ & $22.5 \pm 0.5 \mathrm{meV} \mathrm{bar}^{-1}$ & $33 \pm 0.4 \mathrm{meV} \mathrm{bar}^{-1}$ & & $\begin{array}{c}7.28 \pm 1 \\
{[2]}\end{array}$ & & \\
\hline & & $45 \pm 0.6 \mathrm{meV} \mathrm{bar}^{-1}$ & 4.75 & $\begin{array}{l}5.3 \\
{[11]}\end{array}$ & 2.19 & $2.6[12]$ \\
\hline $\begin{array}{c}\omega_{\mathrm{LA}} \\
(\mathrm{meV})\end{array}$ & $49 \pm 0.5 \mathrm{meV} \mathrm{bar}^{-1}$ & $\begin{array}{c}64 \pm 0.4 \mathrm{meV} \mathrm{bar}^{-1} \\
{[2]} \\
60 \pm 0.6 \mathrm{meV} \mathrm{bar}^{-1} \\
{[9]}\end{array}$ & 5.46 & $\begin{array}{l}7.5 \pm 0.5 \\
{[2]} \\
7.05 \pm 0.7 \\
{[11]}\end{array}$ & 2.51 & $3.4[12]$ \\
\hline
\end{tabular}


with pressure from 4.50 at $P=0$ to 3.78 at $30 \mathrm{kbar}$ indicates a weakening of the electron phonon coupling term. The variations of the energies of phonons, obtained from the second harmonic tunnelling characteristics, are shown in figure 4 . In table I we noted the slopes of the best straight line fits with these data and the corresponding Grüneisen constant $\gamma$, calculated with a bulk modulus equal to $4.6 \times 10^{5}$ bar [13]. The origin of these lines at $P=0$ are the values found by McMillan and Rowell [8]. The Grüneisen values obtained for the phonon energies are smaller in our measurement than the values determined by Franck and Keeler [12]. But these previous experiments have been performed at a pressure lower than ours $(P \sim 3 \mathrm{kbar})$ and it is reasonable to assume a change of the force constants of the atomic interactions with pressure.

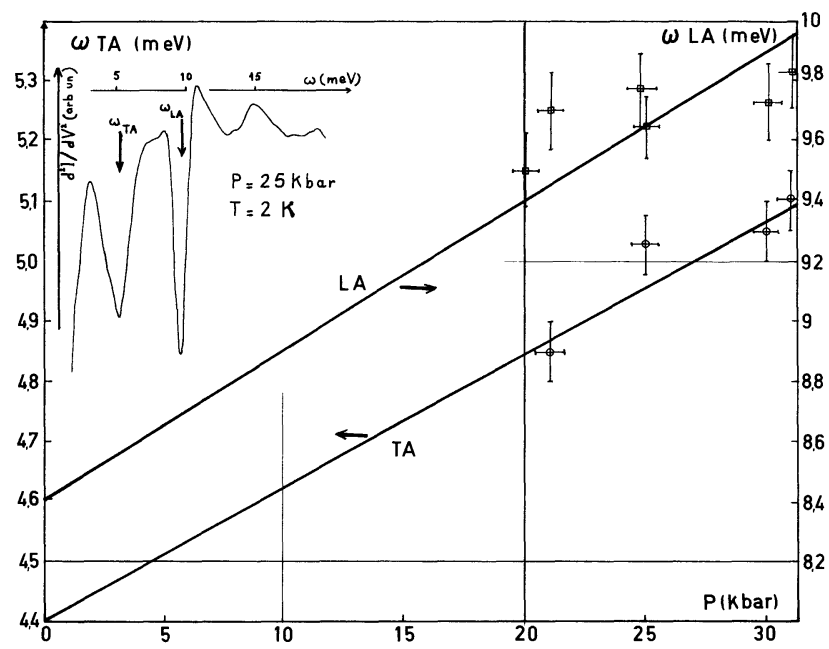

FIG. 4. - Phonons energies TA and LA versus pressure for superconducting lead. The inset is a second harmonic characteristic indicating the measured extrema.

Although a direct measurement of the pressure effects on superconductivity can be performed from the tunnelling density of states using the McMillan program [8], the strong variation of the background tunnelling conductance for Schottky barriers does not yet allow us to use it. Consequently, in order to make an estimate for the pressure dependence of the transition temperature, we have solved the Eliashberg equations [8] for different variations of $\alpha^{2}(\omega) F(\omega)$, the electron-phonon spectral function.

According to Allen and Dynes [14], $T_{\mathrm{c}}$ is given by :

$$
T_{\mathrm{c}}=\frac{\langle\omega\rangle}{1.20} \exp -\frac{1.04(1+\lambda)}{\lambda-\mu^{*}(1+0.62 \lambda)} .
$$

The electron-phonon coupling constant is $\lambda ;\langle\omega\rangle$ is a frequency average on $\alpha^{2}(\omega) F(\omega)$ and $\mu^{*}$ the Coulomb pseudo-potential. The pressure effect is induced in the phonon density of states by assuming that the shift of $\alpha^{2} F$ to higher energies is given by the following formula [13] :

$$
\alpha^{2}(\beta \omega) F(\beta \omega) \sim \frac{1}{\beta^{2}} \alpha_{0}^{2}(\omega) F_{0}(\omega)
$$

where $\alpha_{0}^{2}(\omega) F_{0}(\omega)$ is the phonon density of states at $P=0$. The experimental $\beta$ value for a given pressure is obtained from the measured shift in energy of the phonon structure (Fig. 4). The pressure dependence of $\mu^{*}$ is considered to be small and is neglected [13] : we take the constant value $\mu^{*}=0.13$. Table II gives the transition temperatures obtained following this procedure. It appears that the theoretical values of $T_{\mathrm{c}}$ are systematically lower than the experimental ones but the calculated slope

$$
\frac{\mathrm{d} T_{\mathrm{c}}}{\mathrm{d} P}=(-33.3 \pm 0.5) 10^{6} \mathrm{~K} \mathrm{bar}^{-1}
$$

agrees very well with our experimental determination.

We have also given in table II the theoretical value of the scaling factor $\beta=1-(\Delta V / V) \bar{\gamma}$ where $\bar{\gamma}$ is an average value of the Grüneisen parameter for all the phonons : $\bar{\gamma}$ is chosen equal to 2.85 for $\mathrm{Pb}$ [13] and the variation of $\Delta V / V$ with pressure is given by Miller et al. [15].

\section{TABLE II}

Calculated transition temperatures for different pressures

\begin{tabular}{|c|c|c|c|c|c|c|}
\hline $\begin{array}{c}P \\
\text { bbar }\end{array}$ & $\begin{array}{l}\Delta(0) \mathrm{meV} \\
\text { exp. }\end{array}$ & $\begin{array}{c}\beta \\
\text { exp. }\end{array}$ & $\begin{array}{c}\beta \\
\text { theor. }\end{array}$ & $\begin{array}{l}\langle\omega\rangle \\
\mathrm{meV}\end{array}$ & $\lambda$ & $\begin{array}{c}T_{\mathrm{c}} \\
\text { theor }\end{array}$ \\
\hline- & - & - & - & - & - & \\
\hline 0 & 1.41 & & 1 & 5.21 & 1.57 & 6.54 \\
\hline 10 & 1.27 & 1.051 & 1.063 & 5.4 & 1.39 & 6.23 \\
\hline 20 & 1.125 & 1.131 & 1.13 & 5.9 & 1.2 & 5.96 \\
\hline 25 & 1.05 & 1.16 & 1.142 & 6.06 & 1.2 & \\
\hline 30 & 1 & 1.173 & 1.168 & 6.137 & 1.19 & 5.55 \\
\hline
\end{tabular}
and comparison of $\beta$ parameter with theoretical estimates

Acknowledgments. - We thank D. Jérome and G. Malfait for the use of their high pressure apparatus and for their assistance and E. Guyon for many discussions.

\section{References}

[1] Nédellec, P., Dumoulin, L. and Noer, R. J., J. Phys. F 4 (1974) L-145.

[2] Galkin, A. A., Svistunov, V. M., DikiI, A. P. and TaraNENKo, V. N., Zh. Eksp. Teor. Fiz. 59 (1970) 77 ; (Sov. Phys. JETP 32 (1971) 44).
[3] Guétin, P. and Schreder, G., J. Appl. Phys. 43 (1972) 549.

[4] Delaplace, R., Malfait, G. and Jérome, D., Revue Phys. Appl. 11 (1976) 327.

[5] GuÉtin, P. and Schreder, G., Phys. Rev. B 5 (1972) 3979.

[6] Aspne, D. E., Phys. Rev. B 14 (1976) 5331. 
[7] Pitt, G. D. and Lees, J., Phys. Rev. B 2 (1970) 4144.

[8] McMillan, W. L., Rowell, J. M., Superconductivity, edited by R. D. Parks (Dekker, New York) 1969, p. 561

[9] ZaVaritskiI, N. V., Itskevich, E. S. and Voronovski, A. N., Zh. Eksp. Teor. Fiz. 7 (1968) 271 (JETP Lett. 7 (1968) 211).

[10] Garfinkel, M., Mapother, D. E., Phys. Rev. 122 (1961) 459.

[11] Franck, J. P., Keeler, W. J., Phys. Lett. 25A (1967) 624.
[12] Franck, J. P., Keeler, W. J., Wu, T. M., Solid State Commun. 7 (1969) 483.

[13] Trofimenkoff, P. N., Carbotte, J. P., Phys. Rev. B 1 (1969) 1136.

[14] Allen, P. B. and Dynes, R. C., Phys. Rev. 12 (1975) 905.

[15] Miller, R. A. and Schuele, D. E., J. Phys. Chem. Solids 30 (1969) 589. 